\title{
PROTOTYPE OF A MULTI-USER CHAOS-BASED SYSTEM WITH CORRELATOR AND SUPPORT VECTOR MACHINE RECEIVERS
}

\section{Stevan M. Berber}

The University of Auckland, ECE Department, New Zealand e-mail: s.berber@auckland.ac.nz

ORCID iD: 10http://orcid.org/0000-0002-2432-3088

DOI: 10.5937/vojtehg64-8899

FIELD: Telecommunications, Wireless Communication Systems, Multi-user Systems, Support Vector Machines

ARTICLE TYPE: Original Scientific Paper ARTICLE LANGUAGE: English

\begin{abstract}
:
Multiuser communication techniques are used in modern wireless networks like cellular and wireless sensor networks. The design of the physical layer for these networks was based on the application of binary spreading sequences and a correlation receiver. This paper presents a design of a multiuser code division transceiver using a new method of communication based on the application of chaotic spreading sequences that can increase security of the system, and on a new technique of detecting the received signal using a support vector machine and a traditional correlation receiver. The two receivers are theoretically analyzed, including the derivation of the probability of error expression in a closed form for the fading channel, and then implemented in DSP technology on a 32-bit floating-point TigerSHARC DSP platform. The comparison of two implemented systems showed that the support vector machine solution improves the robustness of the system, sacrificing the speed of processing. The achievable bit rate for the correlator receiver was up to two times higher than for the support vector machine receiver.
\end{abstract}

Key words: Chaos-based communication; SVM and correlator receivers; CDMA systems; DSP desing of CDMA system.

ACKNOWLEDGEMENT: The author is grateful to his summer research project student Shirin Ahmed for her efforts to work on the system prototyping. 


\section{Introduction}

Due to high demands on mobile communications, wireless communication systems and networks are developing faster than ever. Main requirements are to increase capacity of communications links and reduce power consumption of devices, which led to the integration of different types of networks (Šunjevarić, et al, 2013) an their analysis targeted to increase their reliability (Jevtović and Pavlović, 2011). To reduce energy consumption, new techniques of communications are developed and new methods of signal detection are investigated. A support vector machine (SVM) is a machine learning technique which originates from statistical learning. This technique is immensely popular and highly recognized in the fields of data-mining for applications such as speech/music classifier (Lim, et al, 2012), text recognition and DNA micro-array analysis (Kecman, 2001), (Wang, 2005). Recently, there have been some preliminary investigations on applying the SVM as an alternative receiver for CDMA systems because of its ability to mitigate multi-user interference, increase security in signal transmission and adapt to the dynamic communication requirements related to the number of users and characteristics of spreading in the system (Kao and Berber, 2008), (Kao, et al, 2008 and 2010), (Hanzo, et al, 2001), (Yang, et al, 2005), (Kuh, et al, 1999), (Markagić, 2010). However, until now, there is no report on hardware implementation or practical realization of this receiver, which motivated the author to report the research results related to a prototype design of the system.

Recently, chaos-based communication systems have been under extensive development (Tam, et al, 2004), (Cimatti, et al, 2007), (Kaddoum, et al, 2012, 2013), (Berber, et al, 2013) and in particular multi-user CDMA systems that use classical and chaotic spread sequences (Chen, et al, 2001), (Xiao, et al, 2010), (Torrieri, et al, 2010), (Yue, et al, 2010), (Mazzini, et al, 1997), (Rovatti, et al, 1998), where the problem of robust system synchronization was extensively investigated (Kolumban, et al, 1997, 1998, 2000), (Setti, et al, 1999), (Rovatti, et al, 2001), (Berber, et al, 2006), (Jovic, et al, 2007), (Kaddoum, et al, 2009), (Vali, et al, 2010), (Sokolović, et al, 2011). The majority of these papers analysed the systems with a flat fading channel. A detailed analysis of a CDMA system with an assumed wideband, frequency selective channel, was investigated by (Berber, 2014). Due to the limited orthogonality of the spreading sequences, the interuser interference increases with the increase of the number of users in CDMA systems. To overcome this problem of interference, the multiuser detectors are developed (Buehrer, et al, 2000), (Moshavi, 1996), (Poor and Verdu, 1997), (Verdu, 1998), and in particular detectors based on the application of the support vector machine (SVM) technique (Hanzo, et al, 2001), (Yang, et al, 2005), (Kuh, et al, 1999), (Chen and Hanzo, 2002), (Yang and Hu, 2006), (Zhao and Kuh, 2002). 
Although the SVM technique was applied for signal detection, there are no publications presenting its implementation in DSP technology. This fact motivated the author to present his results related to the prototype design and testing of a chaos-based CDMA system. The system with a correlator receiver was also implemented in order to make comparison of this system with the system based on SVM. The bit error rate (BER) properties of both prototypes are compared with the corresponding properties of the theoretical and simulation model. The conducted theoretical and practical analysis showed the advantages of the SVM receiver and good matching of the theoretical and practical results, which presents the first contribution of this paper.

Since the probability of error expression in SVM CDMA systems has not been derived yet, the author made an additional contribution by deriving this expression in a closed form. It was further confirmed that the BER graphs comply with the corresponding graphs obtained by numerical integration (Kao, et al, 2010), which proves the validity of the obtained expression and makes an additional contribution of this paper.

Two systems are compared, one with the SVM and another one with a correlator receiver. It was shown that the correlator receiver can accommodate a higher bit rate than the SVM receiver. As far as complexity is concerned, the SVM requires longer processing time than the correlator receiver. The procedure of comparison and related findings are a valuable contribution of this paper.

This paper has seven sections. Section Two presents the basic characteristics of the chaotic sequences and the operations of a CDMA system. Theoretical modelling and derivative of BER for the correlator and the SVM receiver are presented in Section Three. In particular, a detail derivative for the BER expression of the SVM receiver is shown, which has not been derived yet. A prototype of the system is developed and presented in Section Four. The specific properties of the DSP design of the SVM system are presented in Section Five. The results of the prototype testing and its comparison with the theoretical and simulation models are presented in Section Six. The conclusions are presented in Section Seven.

\section{Multi-user chaos based system operation with the SVM receiver}

\section{Chaotic sequences and their properties}

Chaotic sequences are non-binary sequences with a statistical structure that depends on their initial conditions. Due to their correlation properties, these chaotic sequences, generated using chaotic maps, can 
be used in spread spectrum systems to spread message bits. The maps used to generate chaotic sequences are based on Chebyshev degree- $L$ maps defined by this recursive equation $c_{k+1}=\cos \left(L \cos ^{-1} c_{k}\right)$. The discrete random samples in the sequence $c_{i}$ can take the values between -1 and +1 . For $L=2$, one obtains the logistic map that will be used in this work as the spreading sequence. The samples for this map are generated according to this recursive expression

$$
c_{k+1}=2 c_{k}^{2}-1 \text {, }
$$

The density function for this map is

$$
f_{C_{k}}\left(c_{k}\right)=\frac{1}{2 \sqrt{1-c_{k}^{2}}},
$$

In order to compare chaotic systems with the classical binary system, the chaotic samples need to be generated with the unity average power. There are two methods to achieve this. The first method is to generate chaotic sequences with the average power equal to the power of a binary sequence. In this case, the sample of the chaotic sequence, in this paper denoted by $c_{\mathrm{i}}$, is defined as a linear function of $c_{k}$, i.e., $c_{i}=\sqrt{2} c_{k}$, with a related density function (Berber and Feng, 2013)

$$
f_{C_{i}}\left(c_{i}\right)=\frac{1}{\pi \sqrt{2-c_{i}^{2}}} \text {, for }-\sqrt{2} \leq c_{i} \leq \sqrt{2},
$$

which is symmetric in respect to zero and has the mean square value of one, i.e.,

$$
E\left\{c_{i}^{2}\right\}=\int_{-\sqrt{2}}^{\sqrt{2}} c_{i}^{2} \frac{1}{\pi \sqrt{2-c_{i}^{2}}} d c_{i}=1 .
$$

The second method is to generate chaotic sequences using the recursive expression like (1) and then applying the simple rule: generate +1 if the generated sample is positive or generate -1 if the generated sample is zero or negative. In this case, using different initial conditions, the orthogonal binary sequences of ones and minus ones can be obtained, which has good correlation characteristics. As such, they can be used as spreading sequences in CDMA systems. 
The degree of orthogonality between two sequences generated by the logistic map can be seen in Fig. 1 in which the cross and autocorrelation functions are shown.

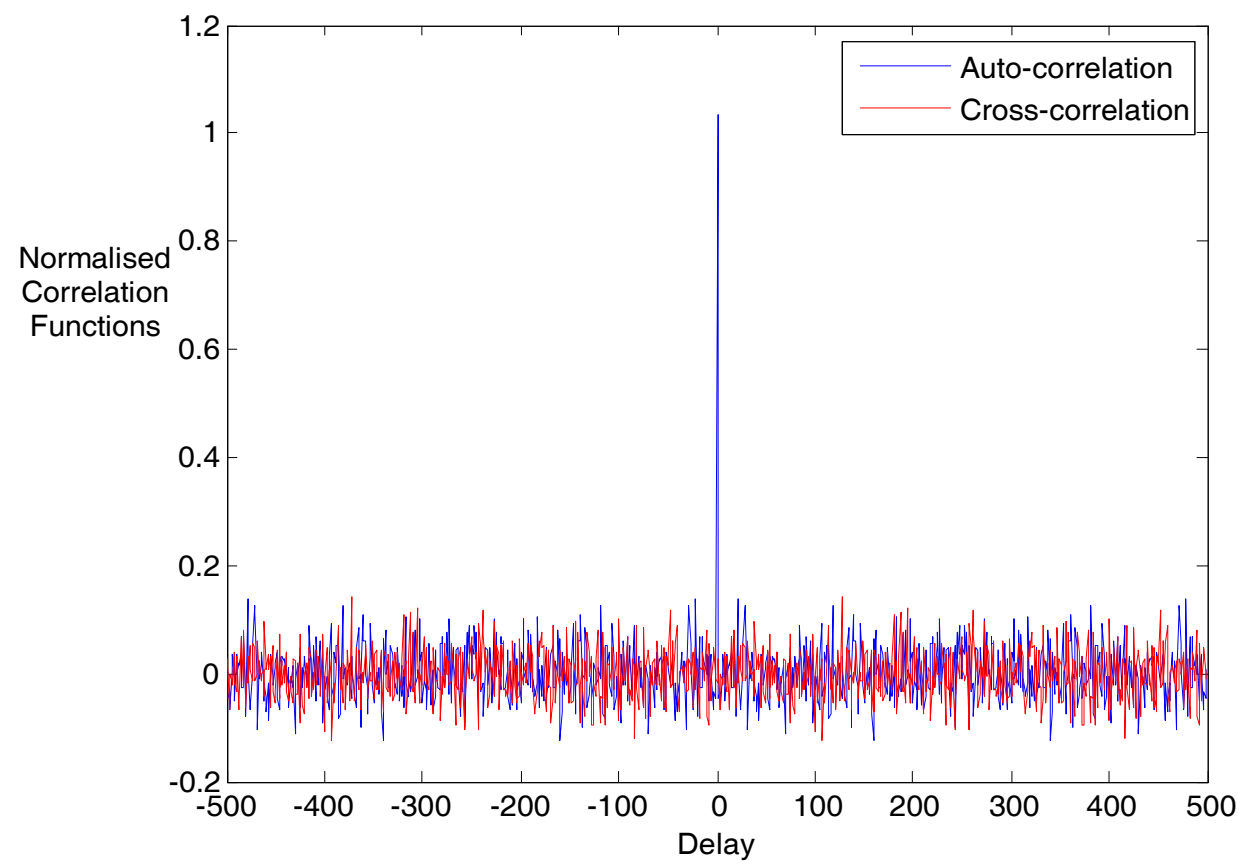

Figure 1 - Autocorrelation and crosscorrelation functions (Berber, 2014)

Puc. 1 - Автокорреляционная и взаимокорреляционная функции (Berber, 2014) Slika 1 - Funkcije korelacije i unakrsne korelacije (Berber, 2014)

As it can be seen, the cross-correlation of two chaotic sequences generated with different initial conditions is close to zero and the autocorrelation function of the same sequence has a peak when it is aligned in time by itself.

\section{Communication system structure and operation}

The basic structure of multi-user communication system, consisting of a transmitter (Tx), a channel and a receiver $(\mathrm{Rx})$ is presented in Fig. 2. The system allows the transmission of $N$ user signals simultaneously. The message bits of $N$ users are spread by $N$ orthogonal spreading chaotic sequences. All spread signals are added to form the transmitter signal $s_{t}$. 


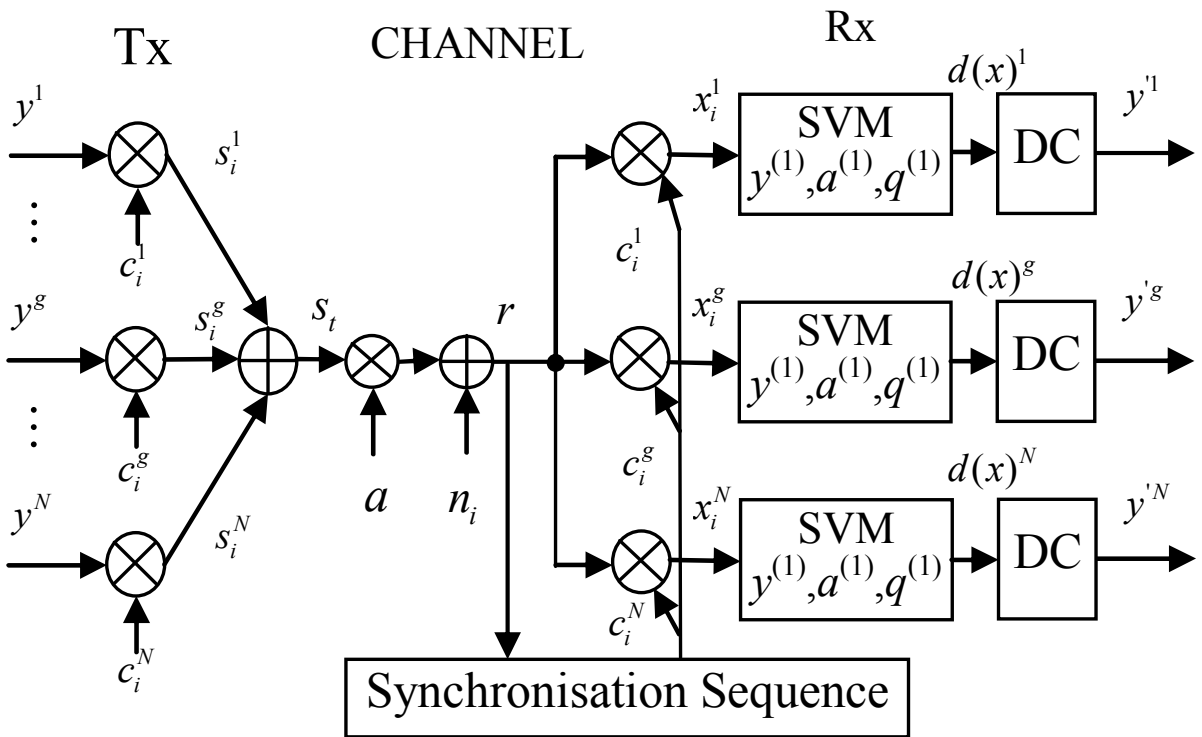

Figure 2 - CDMA sistema structure

Puc. 2 - Структура CDMA системы

Slika 2 - Struktura CDMA sistema

The chips are transmitted through the channel characterized by additive white Gaussian Noise (AWGNC) and Rayleigh fading. This type of channel is adopted due to its possible complex behavior related to the propagation of signals between the transmitter and the receiver and random distribution of bit errors (Radonjić and Gaćeša, 2011). The received signal, containing up to $N$ user signals, is multiplied with the corresponding synchronous spreading sequence to take out the message of a particular user. For example, if only the $g$-th user signal is transmitted, the output of the multiplier for $i$-th chip value can be expressed as

$$
x_{i}=r_{i} c_{i}=y c_{i}^{2}+n_{i} c_{i},
$$

where $c_{i}^{g}=c_{i}$ is the locally generated spread sequence and $r_{i}$ is the received chip. The SVM soft output for this user is $d(x)=d(x)^{g}$ that contains the transmitted message bits (Kao, et al, 2010). This soft value is applied to the input of the decision circuit (DC) which regenerates the estimate of the message bit $y^{g}$ at its output. The $i^{\text {th }}$ bit of the $g^{\text {th }}$ user is denoted by $y=y^{g}$, which can have one of two values taken from the set $\{-1,+1\}$. 
In the case of a correlator receiver, the system structure remains the same except that the SVM block is replaced by an adder that forms the correlator inside the users' receivers (Sandhu and Berber, 2009). The structure of the transmitter remains the same as in Fig. 2.

\section{SVM detector operation}

Unlike the correlator receiver, the SVM receiver has two stages of operation: the initial training or the learning stage, which needs to be performed once only, and the testing stage in which the estimation of the unknown noisy signal actually takes place. The operations of the two stages will be further discussed in the following sections.

1) Training Stage: During this stage, the goal of the SVM is to seek for a separation (hyper) plane which maximizes the margin between the two data-sets of $(+1)$ and $(-1)$ in a $2 \beta$-dimensional space (Kao, et al, 2010). The input training sequence $\mathbf{x}$ is a vector of length $2 \beta$, with the elements given as $x_{i}=r_{i} c_{i}$ where $c_{i}$ are chips in a periodic chip sequence of the length $2 \beta$ (the notation for the user $g$ is omitted in this section for simplicity). Each data sequence $\mathbf{x}$ is associated with a binary message $y \epsilon$ $\{+1,-1\}$ to indicate the desired output.

After the training is completed, the decision function of the linear SVM used here is expressed as (Kao, et al, 2010),

$$
d(\mathbf{x})=\sum_{l=1}^{L} y_{l} \alpha_{l}\left(\mathbf{x}_{i}^{T} \mathbf{x}+1\right)+b,
$$

where $L$ is the number of training sequences, $\alpha_{l}\left(\alpha_{l} \geq 0\right)$ is the Lagrangian dual variable which contributes to the slope of the separation plane and $b$ is the intercept term of a decision hyperplane called bias (Kao, et al, 2010). The small sets of training sequences with non-zero $\alpha_{i}$ are called support vectors (SVs). The training stage only needs to be completed once throughout the entire communication life-cycle, unless the underlying parameters such as the total number of users or the spreading factor have been changed significantly.

2) Testing Stage: When the training is completed, the SVM receiver can begin to estimate the transmitted symbol by making a hard decision in accordance with this decision rule (Kao, et al, 2010)

$$
y^{\prime}=\operatorname{sign}[d(\mathbf{x})] \text {, }
$$

The receiver based on the SVM application solves a classification problem and does not need any knowledge of the spreading sequences of other users (Kao, et al, 2010). 


\section{Probability of error derivations for the SVM} and the correlator receiver for a noisy channel

The theoretical BER of such SVM receiver calculated for the $g$-th user under AWGN has been already derived (Kao, et al, 2010) in this form

$$
p_{n}=\frac{1}{2} \operatorname{erfc} \sqrt{\frac{\left(\sum_{i=1}^{2 \beta} \sum_{s=1}^{N_{S V}} y_{s} \alpha_{s} q_{s, i}+\sum_{s=1}^{N_{S V}} y_{s} \alpha_{s}+b\right)^{2}}{N_{0} \sum_{i=1}^{2 \beta}\left(\sum_{s=1}^{N_{S V}} y_{s} \alpha_{s} q_{s, i}\right)^{2}}},
$$

where $N_{S V}$ is the number of support vectors and $N_{0}$ is the noise power spectral density. In the case when a correlator receiver is used, the probability of error is derived in this form (Sandhu and Berber, 2009)

$$
p_{n c}=\frac{1}{2} \operatorname{erfc}\left[\frac{\psi}{\beta}+\frac{N-1}{\beta}+\left(\frac{E_{b}}{N_{0}}\right)^{-1}\right]^{-1 / 2},
$$

where the value of $\psi$ determines the statistical characteristics of the spreading sequence, $N$ is the number of users in the system, and $2 \beta$ is the spreading factor.

\section{Probability of error derivations for the SVM and the correlator receiver for a fading channel}

In the case of Rayleigh fading presence in the channel, the expression for the probability of error for the SVM receiver has not been published yet. In this case, the presence of fading will affect the received single user signal in such a way that the output of the receiver multiplier (5) will now have this form

$$
x_{i}=a y c_{i}^{2}+n_{i} c_{i},
$$

where $a$ is the fading coefficient that affects all chips inside a bit interval. This expression refers to the signal of a single user. It is important to note that when deriving the probability of error for the SVM receiver, it is sufficient to consider a single user case because the influence of the multiuser interference is not contained at the output of the SVM detector. This 
coefficient will affect the output of the SVM detector expressed by (6), which can be sufficiently accurately expressed as

$$
d(\mathbf{x})=a\left(\sum_{l=1}^{L} y_{l} \alpha_{l}\left(\mathbf{x}_{i}^{T} \mathbf{x}+1\right)+b\right)
$$

and further simplified to (Kao, et al, 2010)

$$
d(x)=a\left[\sum_{s=1}^{N_{S V}} y_{s} \alpha_{s}\left(\sum_{i=1}^{2 \beta} x_{s, i} x_{i}+1\right)+b\right]=a\left(\sum_{i=1}^{2 \beta} x_{i} \sum_{s=1}^{N_{S V}} y_{s} \alpha_{s} x_{s, i}+\sum_{s=1}^{N_{S V}} y_{s} \alpha_{s}+b\right),
$$

Then, the probability of error can be expressed as a random function of the Rayleigh fading coefficient $a$ in this form

$$
p_{n}(a)=\frac{1}{2} \operatorname{erfc} \sqrt{\frac{a^{2}\left(\sum_{i=1}^{2 \beta} \sum_{s=1}^{N_{S V}} y_{s} \alpha_{s} q_{s, i}+\sum_{s=1}^{N_{S V}} y_{s} \alpha_{s}+b\right)^{2}}{N_{0} \sum_{i=1}^{2 \beta}\left(\sum_{s=1}^{N_{S V}} y_{s} \alpha_{s} q_{s, i}\right)^{2}}},
$$

as derived in (Kao, et al, 2010). This expression will be further simplified in this paper and the probability of error in the fading case can be derived in a closed form in accordance with the following procedure. If the signal to noise ratio part in this expression is denoted by

$$
X=\frac{\left(\sum_{i=1}^{2 \beta} \sum_{s=1}^{N_{S V}} y_{s} \alpha_{s} q_{s, i}+\sum_{s=1}^{N_{S V}} y_{s} \alpha_{s}+b\right)^{2}}{N_{0} \sum_{i=1}^{2 \beta}\left(\sum_{s=1}^{N_{S V}} y_{s} \alpha_{s} q_{s, i}\right)^{2}},
$$

the expression for the probability of error can be simplified and expressed as a function of the fading coefficient $a$ as

$$
p_{n}(a)=\frac{1}{2} \operatorname{erfc} \sqrt{a^{2} \cdot X}=\frac{1}{2} \operatorname{erfc} \sqrt{Y},
$$

where $Y$ has a chi-squared probability distribution with two degrees of freedom because $a^{2}$ has the same distribution, which can be expressed as

$$
f_{Y}(y)=\frac{1}{\bar{y}} \exp \left(\frac{-y}{\bar{y}}\right) \text {. }
$$


The probability of error for the Rayleigh fading channel can then be found as the mean value of function (15) and expressed in an integral form as

$$
p_{n f}=E\left\{p_{n}(y)\right\}=\frac{1}{2 \bar{y}} \int_{0}^{\infty} \operatorname{erf} c \sqrt{y} \exp \left(\frac{-y}{\bar{y}}\right) d y,
$$

This integral can be solved using numerical integration. The results of this integration and simulation are presented and discussed in (Kao, et al, 2010). In order to avoid numerical integration, the closed form expression is found in this paper.

By using the property of the error complementary function and its derivatives, and then integrating relation (17) by parts, the expression for the probability of error can be derived in this closed form

$$
p_{n f}=\frac{1}{2}-\frac{1}{2} \sqrt{\frac{\bar{y}}{\bar{y}+1}},
$$

where the mean of $Y$ is $\bar{y}=\bar{Y}=E\left\{a^{2}\right\} X=X$, expressed by because the mean power of fades is equal to one.

In the case when a correlator receiver is used, the probability of error is derived in the closed form (Sandhu and Berber, 2006)

$$
p_{n c}(a)=\frac{1}{2} \operatorname{erfc}\left[\frac{\psi}{\beta}+\frac{N-1}{\beta}+\left(\frac{a^{2} E_{b}}{N_{0}}\right)^{-1}\right]^{-1 / 2},
$$

where $a$ is the fading coefficient, $\psi$ determines the statistical characteristics of the spreading sequence, $N$ is the number of users in the system, and $2 \beta$ is the spreading factor. The mean value of this function in respect to the Rayleigh random variable $a$, which is obtained in an integral form (Sandhu and Berber, 2006), gives the probability of error in the fading channel. However, this integral cannot be solved and numerical integration needs to be used. It is important to note that the probability of error increases enormously due to the fading presence in the channel. Thus, some techniques to mitigate fading should be used. If the block chip interleaving techniques are used, with the block dimensions $2 \beta \times 2 \beta$, the probability of error can be obtained in a closed form as (Berber and Vali, 2011)

$$
p^{g}=\frac{1}{2} \operatorname{erfc}\left(\frac{2+4 N-\pi}{\pi \beta}+\frac{2}{b^{2} \pi}\left(\frac{E_{b}}{N_{0}}\right)^{-1}\right)^{-1 / 2},
$$

where the influence of fading expressed as $b^{2}=1 / 2$ due to the unity power of the fading in the channel. It was proven that the substantial improvement can be achieved using the interleaving technique (Berber and Vali, 2011). 


\section{Design and implementation of the system with both SVM and correlator receivers}

\section{DSP platform for prototyping}

For the design and the implementation of the chaos-based communication system, the ADSP-TS201S TigerSHARC processor from Analog Devices was used (Analog Devices Inc., 2014). Two processors are installed on an evaluation board named TS201S EZ-KIT Lite. The designed CDMA system was implemented on one of these processors. The processors support floating-point data formats, both single-precision 32-bit and extended precision 40-bit, and 8, 16, 32 and 64-bit fixed point data formats. The 32-bit floating-point data format was used in this design because it provides adequate precision for chaotic signal value generation. Although a fixed-point processor is generally faster in executing arithmetic operations, a floating-point processor is necessary when implementing a CDMA system, as a chaotic signal generator and a noise generator would require a wide dynamic range and high precision. Each processor on the EZ-KIT Lite platform has a clock speed of $600 \mathrm{MHz}$, which is capable of executing 2400MIPS, 3600MFLOPS and 1200MMACS (Analog Devices Inc., 2014, Simic and Berber, 2006). This clock speed guarantees that the prototype of the CDMA system will be able to accommodate investigations of the multi-user signal transmission and the probability of error estimation.

The TigerSHARC processor is supported with development tools such as the VisualDSP++ environment, which allows programmers to develop and debug an application. The environment includes an assembler, a library builder, a linker, a loader, a cycle-accurate instruction level simulator, a $\mathrm{C} / \mathrm{C}++$ compiler and a $\mathrm{C} / \mathrm{C}++$ run time library that includes DSP and mathematical functions (Analog Devices Inc., 2014, Simic and Berber, 2006). The evaluation platform comes with a power supply and a USB connector cable that connects the user's PC with the evaluation board, which allows the user to program the processors and debug applications.

The developed prototype was designed using high-level $\mathrm{C}$ programming language. The developed software was fed into the processor as an assembly code using the Visual DSP++ environment. The developed code was loaded into the DSP platform and executed under the control of the external personal computer that was connected to the DSP board. 


\section{System prototype operation}

The CDMA system based on the SVM receiver is designed and implemented in DSP technology. The block schematic of the systems is presented in Fig. 3. The structure of the prototype follows the structure of the theoretical and simulated model presented in Fig. 2. The prototype operates according to this brief description.

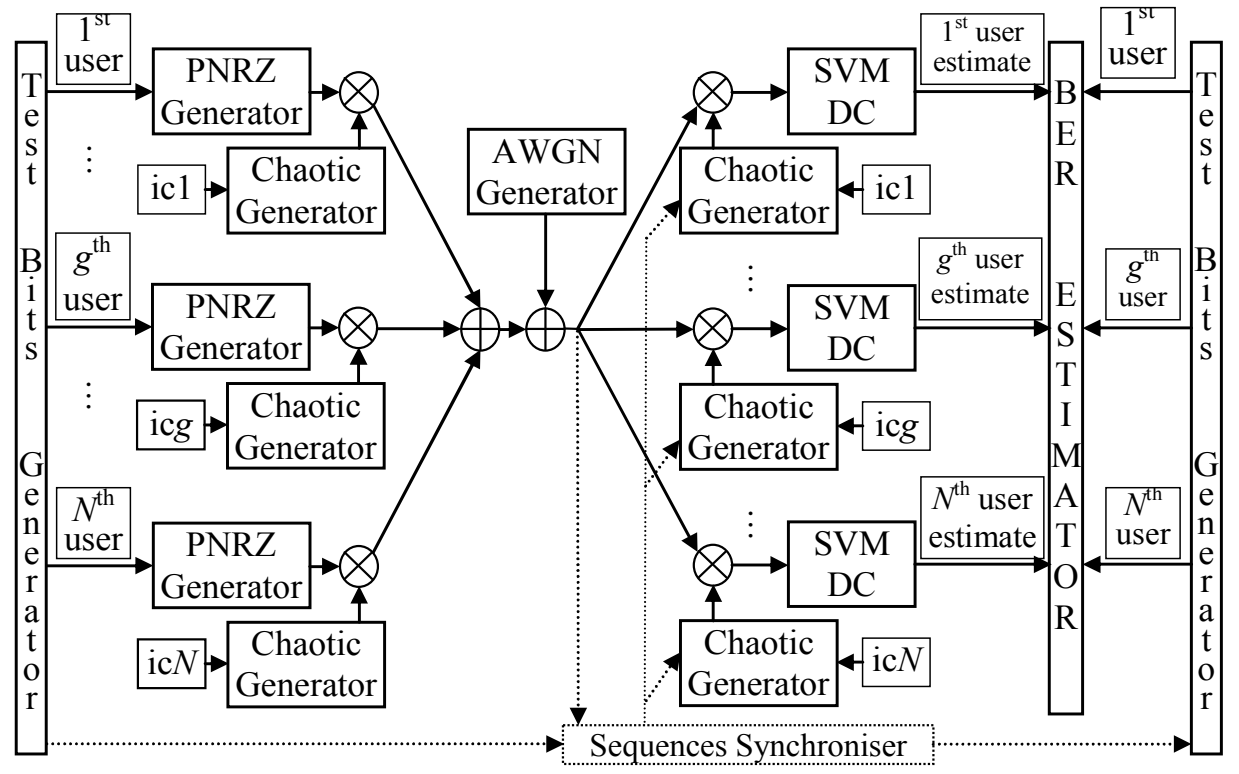

Figure 3 - Structure of the designed and implemented SVM CDMA system Puc. 3 - Структура разработанной и внедренной системы SVM CDMA Slika 3 - Struktura dizajniranog i razvijenog CDMA sistema sa SVM prijemnikom

The independent test pseudorandom sequences, representing users' sequences, are generated for all users and transferred into polar non-return to zero form. The sequences are multiplied (spread) by chaotic orthogonal sequences generated for different initial conditions (ic). Spread signals of all users are added and then transferred through the channel characterized by the Additive Gaussian Noise, obtained for the designed noise generator.

At the receiver side, the blocks of Chaotic Generators, SVM detectors and decision circuits (DC) are implemented for the reception of the signals and generation of the estimates of the bit received. 
The estimated bit samples are compared with the synchronous locally generated user sequence and the bit error rate (BER) values are calculated as the ratio of the number of errors counted and the number of bits transmitted. The test bit generators at the transmitter side are synchronized with the bit samples obtained at the output of the decision circuit.

When the receiver operates with the correlator instead of the SVM, the SVM detector is replaced by an accumulator. In this case the remaining structure of the transmitter and the BER estimator are the same as in Fig. 3.

\section{Test Bit Generator}

The Test Bit Generator is designed as a 16-bit Fibonacci linear feedback shift register (LFSR), which has taps at the position of bits 11, 13, 14 and 16. With an even number of taps, it is possible for the LFSR to cycle through all possible states $\left(2^{n}-1\right.$ states, where $n$ is the length of the LFSR) except when all values are zero. In this design, the Bit at LFSR tap 10 was extracted as the output, and used as a user bit value. The following condition was set on generated bits: if the input bit value is zero, then the output bit value would be equal to -1 . This established the function of a polar non-return to zero (PNRZ) encoder, as shown in Fig. 3. Every time the bit generator function was called, another bit value would be outputted. The bit generator function was used to generate message bits to feed into the transmitter function, and was also used to compare these bits in the BER calculator function with the received bit values. The bit generator would be reset (i.e. started from the beginning) when the BER calculation for a particular SNR value was complete. For this purpose, the synchronization between the estimated bit values at the receiver and the generated message bit values was established.

\section{Chaotic sequence generators}

Chaotic sequence generators were implemented in the discrete time domain where a particular chaotic signal value is derived from the chaotic signal value at the previous sampling time instant. For the chaotic generators implemented in DSP, the chaotic logistic map was used that is defined according to expression (1).

The values of a certain sequence are highly dependent on the initial condition (ic) which is independently generated for each user. According to the theory, by altering the initial condition slightly, the resultant sequences 
can be a completely different and aperiodic. However, due to the inherent limited precision of DSPs, chaotic sequences tend to become periodic. Previous investigations of chaos-based communication systems have observed a range of initial conditions, and recorded corresponding discrete time periods, after which each sequence would start repeating itself (Vukadinovic and Berber, 2006). In the design presented in this paper, in order to avoid this periodicity, the following rule was applied: if the sequence reaches the time period value specified for that particular initial condition, the sequence is restarted with the same initial condition. The chaotic sequence generators are reset upon the completion of the BER calculation for a single SNR value.

\section{Gaussian Noise samples}

Gaussian noise samples are generated using the Box-Muller method which is based on generating two uniformly distributed samples $U_{1}$ and $U_{2}$ using the $\operatorname{rand}(\cdot)$ function. These variables were then normalized by dividing by the RAND_MAX constant, which is defined in the library header file. $U_{1}$ and $U_{2}$ were then utilized by the Box Muller transform stated by (21) to produce the sample $W$ which is a sample of a random variable having Gaussian distribution

$$
W=\sqrt{\left(-2 \ln \left(U_{1}\right)\right.} \cos \left(2 \pi U_{2}\right)
$$

The generated samples are having zero mean and unity variance. To generate samples for different SNR values, the Gaussian samples need to be multiplied by the value of the noise variance (Simic and Berber, 2006). The Gaussian value generator outputs the Gaussian sample. It is reset after each bit is decoded.

The signal to noise ratio (SNR) was changed by changing the noise power. For that purpose, a generator function was implemented that calculates the noise variance value for the desired SNR. The function takes the current SNR value and a reset value as inputs. It then calculates the energy of the current message bit, by squaring and summing the chaotic sequence values for the current message bit. Then it calculates the sigma value required for noise generation as

$$
\sigma=\sqrt{\frac{E_{b}}{2 \cdot 10^{S N R / 10}}},
$$


The sigma generator then outputs the sigma value calculated to the noise generator function. The sigma generator function is reset once the BER calculation for a single SNR value is complete.

The noise generator takes in the sigma value generated from the sigma generator for a particular message bit and a reset value as inputs. By multiplying the sigma value with the Gaussian sample generated, the resulting noise sample is then obtained at the output. In the main file, the noise generator is called on a per chip basis, and is added to the output of the transmitter function.

\section{BER estimator}

To evaluate the performance of the prototype system, the bit error rate (BER) was estimated by firstly setting an error threshold of 1000 errors, which gives a very high level of estimation accuracy obtained according to the method presented in (Berber, 1989).

The BER calculator function takes in the decision value from the SVM detector (or the correlator) and the bit generator output, and compares the two. If the values are not equal to one another, an implemented error counter increments by 1 . Message bits are generated, transmitted, received and decoded until the error counter equals the error threshold. Once this happens, the total number of bits sent to achieve the threshold of 1000 errors is recorded. By dividing the error threshold by the number of bits sent, the BER for that particular SNR value, for defined both the number of users and the spreading factor, is calculated.

Once the theoretical BER and the BER of the system in DSP are calculated for a certain SNR value, the system repeats the same procedure for other SNR values if specified. The BER results are then stored in a text file in the debug folder.

\section{Specific DSP design of the SVM detector and the decision circuit}

Training phase

To generate support vectors, training data for a defined number of users and the spreading factor had to be generated first. Training data is made up of a number of samples from the output of the correlator function. A block diagram of the program implemented on the DSP to generate the training data is shown in Fig. 4. 


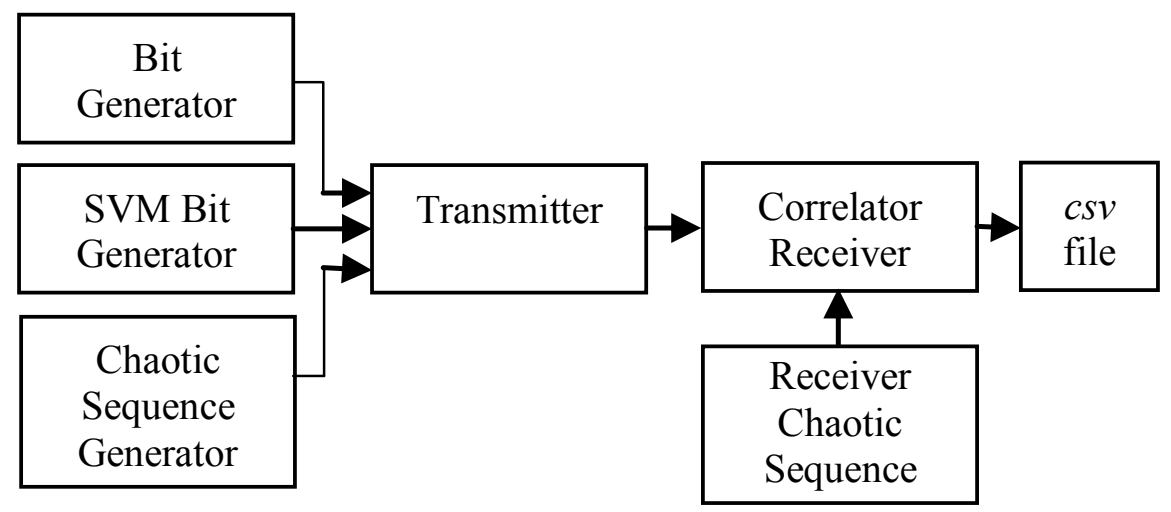

Figure 4 - Functional block diagram of the system for the training phase

Puc. 4 - Функциональная блок-схема системы для фразы подготовки Slika 4 - Principski blok dijagram sistema u fazi treninga

The number of samples required for training depends on the SNR value. For this design, training data was subjected to no noise. Hence, 200 sample message bits sufficed: a hundred message bits of value +1 and a hundred message bits of value -1 . The spreading factor was set to 20 as an appropriate number for this purpose (Kao, et al, 2008). The message bits were generated using a function called the SVM Bit Generator, as shown in Fig. 4, which generated 200 message bits that were assigned to the desired user only, while the interferers' user bits were generated from the Bit Generator function. Message bits for the desired user and message bits for interferers are spread with a chaotic sequence (Kao, et al, 2008), which was taken as an input from the Chaotic Sequence Generator.

The output of the transmitter function was taken as an input by the correlator function. The Receiver Chaotic Sequence block generates the desired user's chaotic sequence to be correlated with the incoming received sequence. The results of this correlation are stored in a csv file. Hence, after all 200 sample message bits are transmitted, the csv file would contain the each message bit value and the corresponding correlation values, which represents the training data that can be used to generate support vectors.

To generate support vectors using the training data stored in the csv file, training was carried out by the iterative single data algorithm (Kao, et al, 2008). The result of this training is a data file that contained the parameters such as weights, centers and bias values of the support vectors. To extract these parameters, a program created in Matlab was fed with this data file, and the parameters were stored in separate text files, which were then read by the program in DSP. 
The implemented program first reads the weights, centers, bias values and the number of support vectors from the text files, which have been generated from the training data for a particular number of users. For additional users, or a change in the spreading factor, the training phase would have to be repeated to get a different set of support vectors, because the number of support vectors depends on the spreading factor and the number of users in the system. For example, for 2 users, and a spreading factor of 20, 3 support vectors were generated. However, if the number of users increases to 8,20 support vectors would be generated.

The purpose of the SVM function is to compute the decision function defined by (6). At this point, it is necessary to make these observations. In equation (6), $L$ is the number of support vectors generated for a particular number of users and the spreading factor, the variable $y_{l} \alpha_{l}$ is the weight that is generated for each support vector. The variable $x_{i}$ represents the centers generated for each support vector. The number of centers for each support vector is of the spreading factor length, and each center is multiplied with each corresponding output value of the correlator denoted by $x$. The value $b$ is the bias value. The SVM function computes the decision function for all the support vectors generated, and outputs a value which is fed into the decision circuit. This decision function is used to calculate the probability of error in (13) and (18), where the appropriate notation is used.

\section{Results of the investigation and the comparison of the prototype with the theoretical and the simulation model}

\section{Probability of error analysis in the noisy channel}

The bit error rates, for the system with the SVM and the correlator receiver implemented in DSP technology, are calculated after the support vector parameters were loaded onto the DSP. The BER for the CDMA system performance with the SVM incorporated in the receiver was measured for the SNR value range of $-1 \mathrm{~dB}$ to $8 \mathrm{~dB}$ and the results are presented in Fig. 5 for a single user system. This BER curve is plotted against the simulation and theoretical curves investigated previously in (Kao, et al, 2008, 2010). The theoretical curves for the system with a correlator receiver, and with the SVM incorporated into the receiver are shown, along with the BER results from the Matlab simulations and the DSP prototype. 
The SVM receiver has better BER performances than the correlator receiver. The SVM BER curves obtained by the theory are overlapping with the curve obtained by the simulation. The BER curve obtained by DSP SVM receiver follows quite closely the simulation curve. The improvement in the BER of the SVM in respect to the correlator receiver increases when the SNR increases.

This improvement in the BER is expected to be higher when the number of users increases due to the ability of the SVM receiver to eliminate the interuser interference. For this reason, the communication system was investigated for 4 active users in the system and the related BER curves are presented in Fig. 6

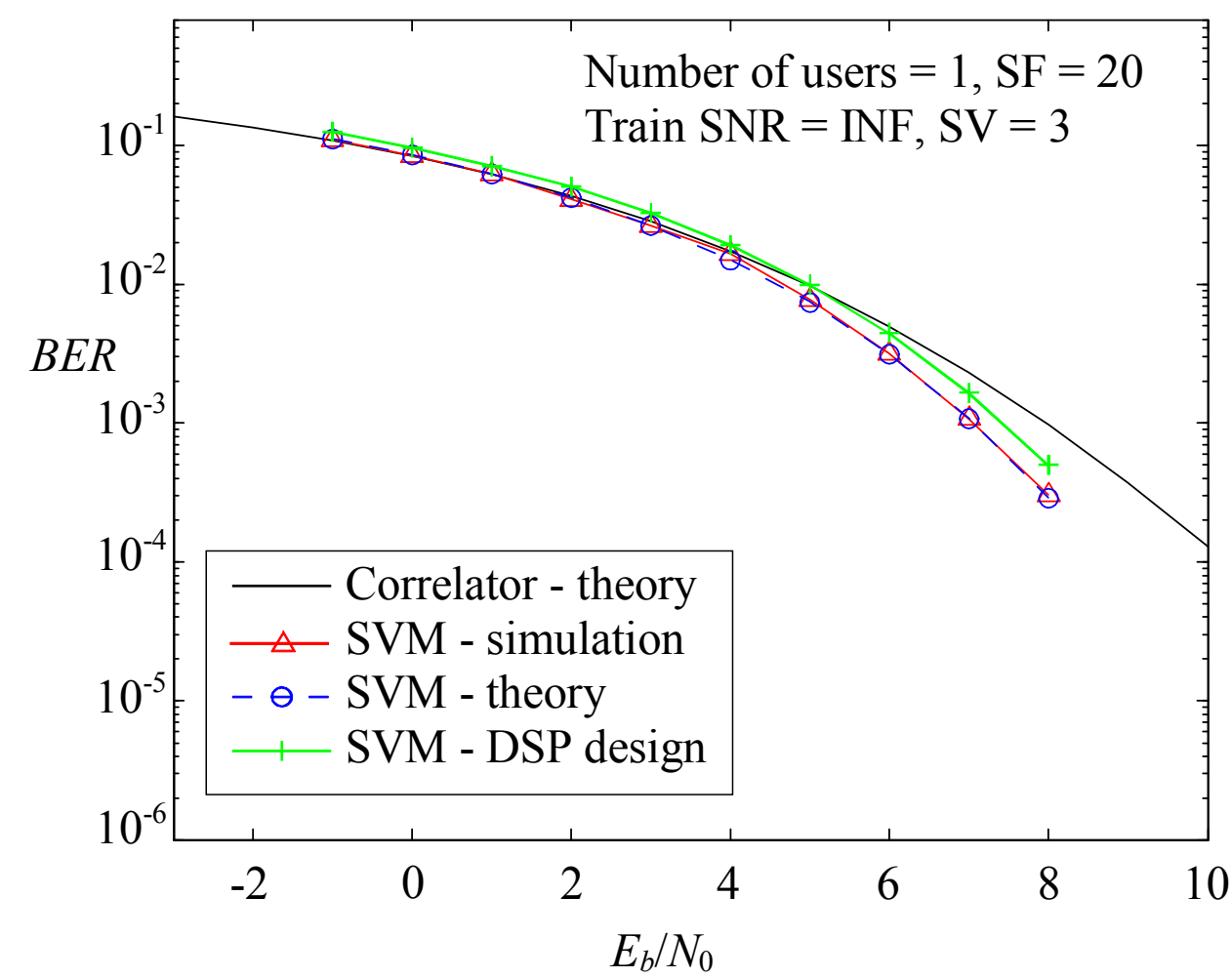

Figure 5-BER curves, theoretical, simulated and DSP results for the system with the SVM for 1 user

Puc. 5 - Кривые вероятности битовой ошибки (BER), полученные при теоретическом моделировании и DSP результатах для системы SVMc одним пользователем

Slika 5 - Grafovi verovatnoće greške bita (BER) dobijeni prema teorijskim, simulacionim i DSP rezultatima za sistem sa SVM i za slučaj jednog učesnika 
Firstly, it can be observed that the DSP BER curves match perfectly the simulation and theoretical curves obtained by relation (8). Secondly, the figure shows that the improvement in the BER of the SVM in respect to the correlator receiver increases substantially when the SNR increases. This matches perfectly well the theory which states that the SVM receiver eliminates the influence of the inter user interference. Namely, when the SNR is small, less than $2 \mathrm{~dB}$ in this case, the noise dominates and the $\mathrm{BER}$ is close to the correlator receiver.

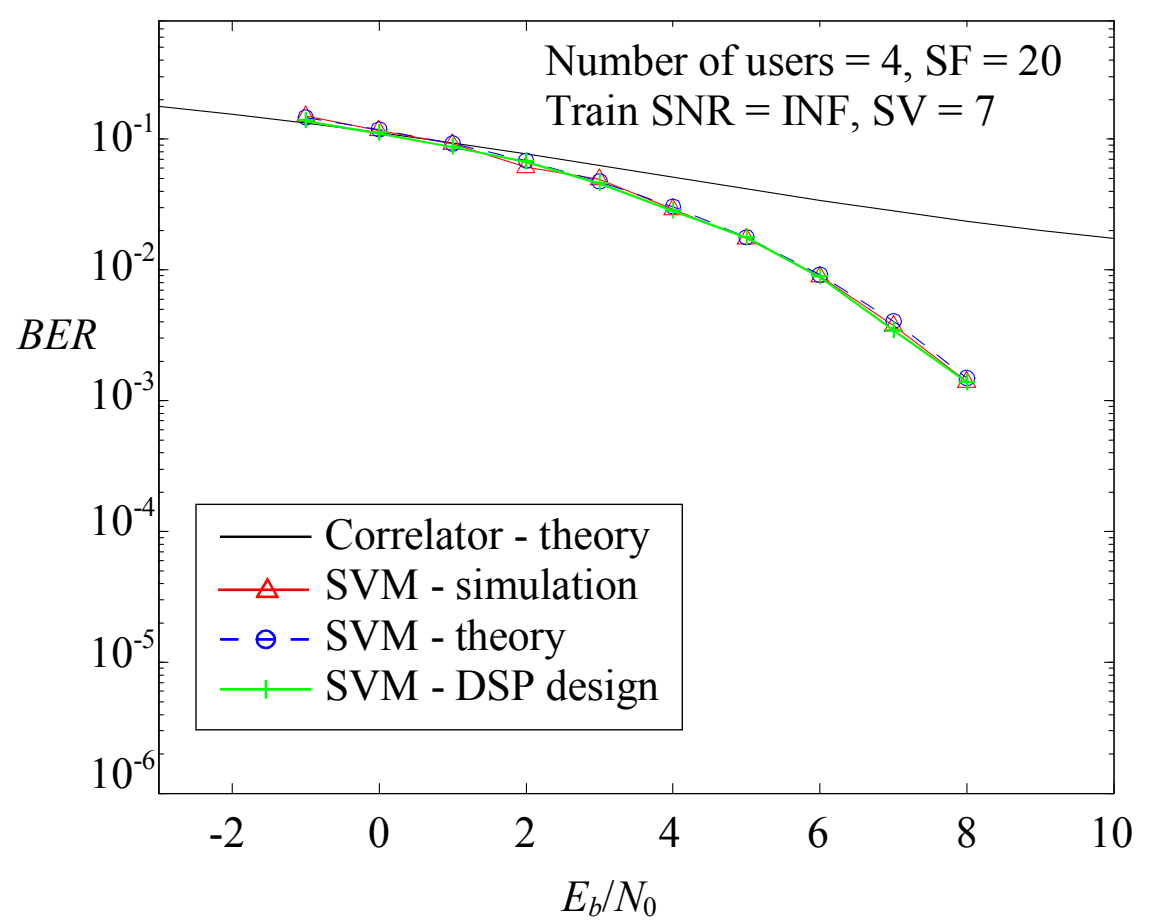

Figure 6 - Theoretical, simulated and SVM DSP BER curves for the CDMA system for 4 users. A theoretical BER curve for the correlator receiver is added for comparison.

Puc. 6 - Кривые вероятности битовой ошибки (BER), полученные при теоретическом моделировании и DSP результатах для системCDMA и SVMc четырьмя пользователями. Теоретическая BER кривая корреляционного приемника приведена для сравнения

Slika 6 - Grafovi verovatnoće greške bita (BER) dobijeni prema teorijskim, simulacionim i DSP rezultatima, za CDMA sistem sa SVM i za slučaj četiri učesnika.

Teorijska BER kriva za korelatorski prijemnik je dodata radi upoređenja

However, when the SNR increases, then the BER improves in the SVM receiver due to the elimination of the inter-user interference. The curves for the correlator receiver have significantly higher BER values in this case due to the presence of interuser interference. 


\section{Probability of error analysis in the fading channel}

In this paper, the closed form theoretical expression for the probability of error is derived in Section Three and expressed by (18). The BER graphs obtained by both that expression and the simulation are presented in Fig. 7 for two cases, when the number of users in the system is either 10 or 30.

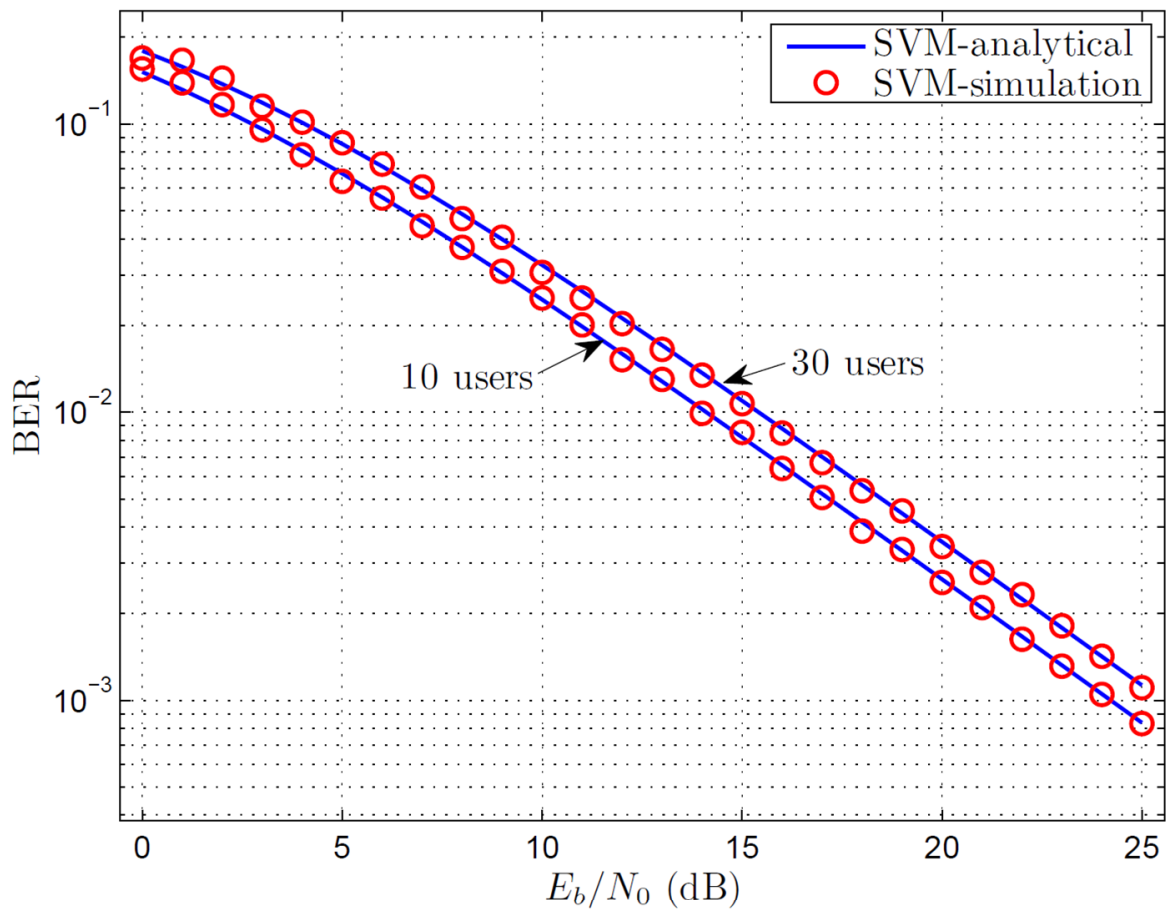

Figure 7 - BER curves obtained by both the theoretical expression in the closed form and the simulation

Рис. 7 - Кривые вероятности битовой ошибки (BER), полученные при теоретическом моделировании в закрытом канале

Slika 7 - Grafovi verovatnoće greške bita (BER) dobijeni prema teorijskom izrazu u zatvorenom obliku i na osnovu simulacije

In both cases the theoretical curves are matching very well the simulation curves. These curves are matching also the curves obtained by numerical integration as presented in reference (Kao, et al, 2010). The difference between a 10-user and a 30-user system are close to $1 \mathrm{~dB}$. This result is expected because the CDMA system with the SVM detector eliminates the inter-user interference very well. 
The main purpose of this investigation related to the speed estimation was to compare the difference between the bit rates of the CDMA system implemented using the correlator receiver and the system with the SVM receiver. For this purpose $10^{4}$ message bits were transmitted and received in both systems. The time taken for processing was measured for the spreading factor of 20. Fig. 8 shows the bit rates as a function of the number of users for both systems. The clock cycles, which are necessary to execute the relevant code, were measured and converted to the bit rate according to this expression

$$
R_{b}=\frac{B \cdot f_{c}}{C \cdot N}
$$

where $R_{b}$ is the bit rate, $B$ is the number of bits sent, $f_{c}$ is the clock frequency, $C$ are clock cycles and $N$ is the number of users.

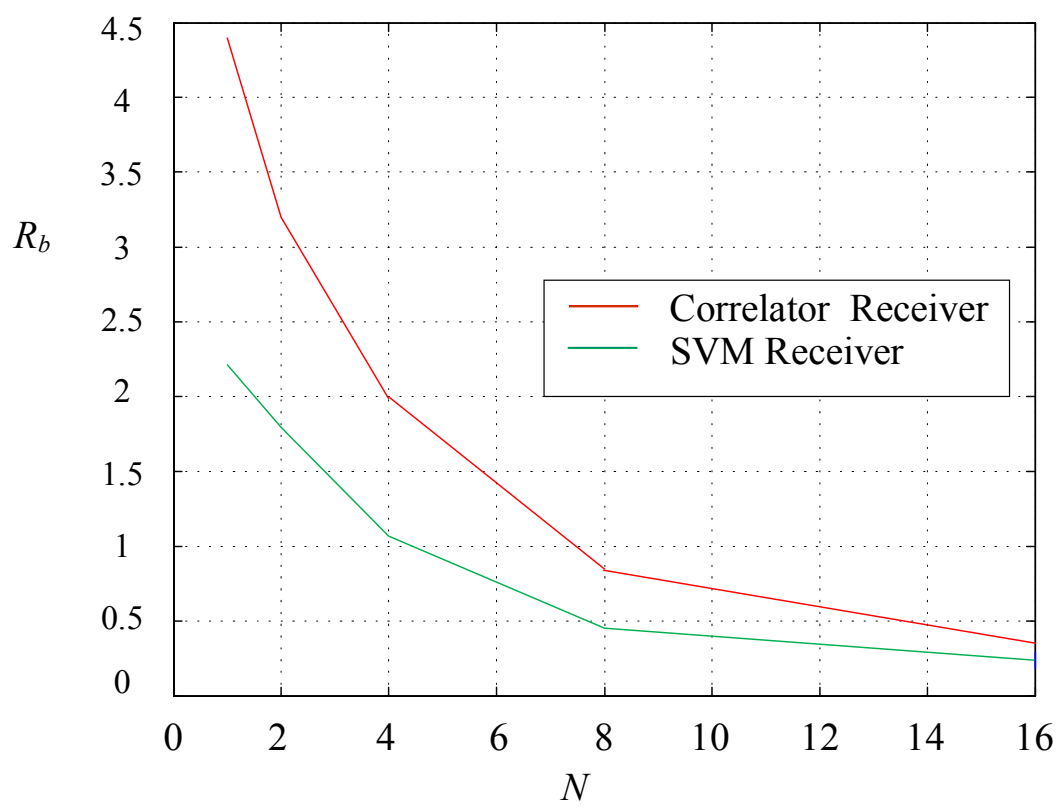

Figure 8 - Speed estimation for the system with the correlator receiver and the SVM receiver for a different number of users

Puc. 8 - Средняя скорость для системы корреляционного и SVM приемника с разным кол-вом пользователей

Slika 8 - Prosečna brzine za sistem sa korelatorskim i SVM prijemnicima za različiti broj učesnika 
It was found that the bit rate was 1.5 to 2 times higher for the system with the correlator receiver than for the system with the SVM. Namely, in the SVM receiver, more computation is involved, and hence more processing time is required.

Therefore, from the BER performance results, it can be concluded that, by incorporating the SVM into the receiver, the performance of the system increases significantly in respect to the correlator receiver. However, the execution speed on DSP reduces considerably.

\section{Conclusion}

The design of a prototype CDMA system with a SVM receiver is implemented on the 32-bit floating point ADSP-TS201S TigerSHARC processor. The prototype was developed by creating functions in C language, and was programmed on the processor situated on a TS201S EZ-KIT Lite evaluation platform. It was confirmed that the robust prototype can be designed on this platform.

The training phase was performed to generate the support vectors via programs in Matlab software. The theoretical expression for the probability of error was derived in the closed form in the case when fading is present in the channel. The bit error rate (BER) measurement in the prototype system confirms that the SVM receiver performs better than the corresponding correlator receiver. The BER performance of the prototype matches theoretical and simulation results for varying both the spreading factor and the number of users.

The expected problem of the periodicity of spreading sequences due to the finite resolution of the DSP operations was solved by the reinitializing the chaotic sequence generators. Because the theoretical and simulation results matched very well the DSP results, it is obvious that the DSP resolution does not influence the performance of the system.

The results of the speed estimation analysis show that the CDMA system with the correlator receiver has a higher bit rate than the CDMA system with the SVM receiver, due to larger computation with support vectors. The speed in signal processing of the presented prototype is not sufficient to accommodate increasing demands in bit rates. However, a valuable experience is gained in system design and a possible speed increase through both the optimization of the existing processing algorithms and the application of the new DSP technologies. One of the streams of future research could be to make a prototype of the system in the case when fading is present in the channel and the methods of fading mitigations are applied, like chip interleaving. 


\section{References}

Analog Devices Inc. (2006). . Data Sheets. Retrieved from www.analog.com/static/ imported-files/data_sheets/ADSP_TS201S.pdf

Berber, S. 1989. Techniques for Bit Error Rate Measurement Using Chebyshev Inequality. Electronics Letters, 25(14), pp.927-929.

Berber, S., \& Jovic, B. 2006. Sequence synchronization in a wideband CDMA system. . In: Proceedings of the 2006 International Conference on Wireless Broadband and Ultra Wideband Communications (AusWireless06), Sydney, Australia, pp.1-6.

Berber, S.M., \& Vali, R. 2011. Fading Mitigation in Interleaved Chaos-Based DSCDMA Systems for Secure Communications.. In: 15th WSEAS Int. Conf. on Communications, Corfu, Greece, pp.1-6.

Berber, S., \& Feng, S. 2013. Chaos-Based Physical Layer Design for WSN Applications. . In: 17th WSEAS Int. Conf. on Communications, Rhodes, Greece, pp.157-162.

Berber, S., \& Feng, S. 2013. Theoretical Modelling and Simulation of a Chaos-Based Physical Layer for WSNs. International Journal of Communications, 7(2), pp.27-34.

Berber, S.M. 2014. Theoretical Analysis and Simulation of a Code Division Multiple Access System (CDMA) for Secure Signal Transmission in Wideband Channels. Vojnotehnički glasnik/Military Technical Courier, 62(3).

Buehrer, R.M., Correal-Mendoza, N.S., \& Woerner, B.D. 2000. A simulation comparison of multiuser receivers for cellular CDMA. IEEE Transactions on Vehicular Technology, 49(4), pp.1065-1085. doi:10.1109/25.875213.

Chen, S., \& Hanzo, L. 2002. Block-adaptive kernel-based CDMA multiuser detection. . In: Proc. IEEE Int. Conf. Comm, pp.682-686 vol. 2. April, pp.682-686.

Chen, S., Samingan, A.K., \& Hanzo, L. 2001. Support vector machine multiuser receiver for DS-CDMA signals in multipath channels. IEEE Transactions on Neural Networks, 12(3), pp.604-611. doi:10.1109/72.925563.

Cimatti, G., Rovatti, R., \& Setti, G. 2007. Chaos-Based Spreading in DS-UWB Sensor Networks Increases Available Bit Rate.IEEE Transactions on Circuits and Systems I: Regular Papers, 54(6), pp.1327-1339. doi:10.1109/TCSI.2007.895378.

Jevtović, V.M., \& Pavlović, Z.B. 2011. Topološka analiza telekomunikacionih mreža. Vojnotehnički glasnik/Military Technical Courier, 59(1), pp.96-110.

Jovic, B., Unsworth, C., Sandhu, B., \& Berber, S. 2007. A robust sequence synchronization unit for multi-user DS-CDMA chaos-based communication systems. Signal Processing, 87(7), pp.1692-1708.

Kaddoum, G., Roviras, D., Charge, P., \& Fournier-Prunaret, D. 2009. Robust synchronization for asynchronous multi-user chaos-based DS-CDMA. Signal Processing, 89(5), pp.807-818.

Kaddoum, G., \& Gagnon, F. 2012. Design of a High-Data-Rate Differential ChaosShift Keying System. IEEE Trans. Circuits Syst, 59(7), pp.448-452.

Kaddoum, G., Richardson, F.D., \& Gagnon, F. 2013. Design and Analysis of a Multi-Carrier Differential Chaos-Shift Keying Communication System. IEEE Tr. on Comm., 61(8), pp.3281-3291.

Kao, J., \& Berber, S.M. 2008. Demodulation of a chaos-based CDMA system using support vector machine. In: 3rd International Symposium on Wireless Pervasive Computing, ISWPC. pp.69-72.

Kao, J., Berber, S.M., \& Kecman, V. 2008. Blind Multi-User Detection of a ChaosBased CDMA System Using Support Vector Machine.. In: IEEE 10th International Symposium on Spread Spectrum Techniques and Applications, ISSSTA '08, pp.58-62. 
Kao, J., Berber, S.M., \& Kecman, V. 2010. Blind Multi-User Detector of a ChaosBased CDMA Using Support Vector Machine.IEEE Transactions on Neural Networks, 21(8), pp.1221-1231.

Kecman, V. 2001. Learning and Soft Computing: Support Vector Machines, Neural Networks, and Fuzzy Logic Models.MIT Press.

Kolumban, G., Kennedy, M.P., \& Chua, L.O. 1997. The role of synchronization in digital communications using chaos. I . Fundamentals of digital communications. IEEE Transactions on Circuits and Systems I: Fundamental Theory and Applications, 44(10), pp.927-936. doi:10.1109/81.633882.

Kolumban, G., Kennedy, M.P., \& Chua, L.O. 1998. The role of synchronization in digital communications using chaos. II. Chaotic modulation and chaotic synchronization. IEEE Transactions on Circuits and Systems I: Fundamental Theory and Applications, 45(11), pp.1129-1140. doi:10.1109/81.735435.

Kolumban, G., \& Kennedy, M.P. 2000. Communications using chaos»MINUS. III. Performance bounds for correlation receivers. IEEE Transactions on Circuits and Systems l: Fundamental Theory and Applications, 47(12), pp.1673-1683. doi:10.1109/81.899919.

Kuh, A., \& Gong, H. 1999. Support Vector Machine for Multiuser Detection. . In: CDMA Communications, Thirty-Third Asilomar Conference on Signals, Systems, and Computers. vol. 1, pp.680-684.

Lim, C., Lee, S.R., \& Chang, J.H. 2012. Efficient Implementation f an SVM-Based Speech/Music Classifier by Enhancing Temporal Locality in Support Vector References. IEEE Transactions on Consumer Electronics, 58(3), pp.898-904.

Li-Mei, C., \& Bor-Sen, C. 2001. A robust adaptive DFE receiver for DS-CDMA systems under multipath fading channels. IEEE Transactions on Signal Processing, 49(7), pp.1523-1532. doi:10.1109/78.928705.

Markagić, M.S. 2010. Komunikacioni kanal sa šifrovanjem informacija. Vojnotehnički glasnik/Military technical Courier, 58(3), pp.88-104.

Mazzini, G., Setti, G., \& Rovatti, R. 1997. Chaotic complex spreading sequences for asynchronous DS-CDMA. I. System modeling and results. IEEE Transactions on Circuits and Systems I: Fundamental Theory and Applications, 44(10), pp.937-947, doi:10.1109/81.633883.

Mazzini, G., Rovatti, R., \& Setti, G. 2001. Chaos-based asynchronous DS-CDMA systems and enhanced rake receivers: measuring the improvements. IEEE Transactions on Circuits and Systems I: Fundamental Theory and Applications, 48(12), pp.1445-1453. doi:10.1109/TCSI.2001.972851.

Moshavi, S. 1996. Multi-user detection for DS-CDMA communications. IEEE Communications Magazine, 34(10), pp.124-136. doi:10.1109/35.544334.

Poor, H.V., \& Verdu, S. 1997. Probability of error in MMSE multiuser detection. IEEE Transactions on Information Theory, 43(3), pp.858-871. doi:10.1109/18.568697.

Radonjić, V.M., \& Gaćeša, N.N. 2011. Uticaj sredine na prostiranje elektromagnetnih talasa kod digitalnih radio-relejnih uređaja GRC 408E. Vojnotehnički glasnik/Military Technical Courier, 59(1), pp.40-61.

Rovatti, R., Setti, G., \& Mazzini, G. 1998. Chaotic complex spreading sequences for asynchronous DS-CDMA. Part II. Some theoretical performance bounds. IEEE Transactions on Circuits and Systems I: Fundamental Theory and Applications, 45(4), pp.496-506. doi:10.1109/81.669073. 
Rovatti, R., Mazzini, G., \& Setti, G. 2001. Enhanced rake receivers for chaos-based DS-CDMA. IEEE Transactions on Circuits and Systems I: Fundamental Theory and Applications, 48(7), pp.818-829. doi:10.1109/81.933323.

Sandhu, G.S., \& Berber, S. 2006. Investigation On Orthogonal Signals For Secure Transmission In Multiuser Communication Systems. . In: The 1st International Conference on Wireless Broadband and Ultra Wideband Communications AusWireless'06, Sydney, Australia, pp.1-6.

Sandhu, G.S., \& Berber, S. 2009. Theoretical Model, Simulation Results and Performances of a Secure Chaos-based Multi-user Communication System. International Journal of Network Security, 8(1), pp.25-30.

Setti, G., Rovatti, R., \& Mazzini, G. 1999. Synchronization Mechanism and Optimization of Spreading Sequences in Chaos-Based DS-CDMA Systems. IEICE TRANS. on Fundamentals of Elec., Commun. And Computer Sciences, 9, pp.1737-1746.

Simic, Lj., \& Stevan, B.M. 2006. Performance Analysis of a Chaos-Based MultiUser Communication System Implemented in DSP Technology. . In: The 1st International Conference on Wireless Broadband and Ultra Wideband Communications AusWireless'06, Sydney, Australia, pp.1-6.

Sokolović, B.C., Oklopdžija, M.N., \& Marković, G.B. 2011. Izbor metoda sinhronizacije u softverskom GPS prijemniku.Vojnotehnički glasnik/Military Technical Courier, 59(2), pp.94-110.

Šunjevarić, M.M., Popović, M.L., \& Todorović, B.M. 2013. Integracija digitalne radiodifuzne mreže mobilne televizije i ćelijske mreže treće generacije. Vojnotehnički glasnik/Military Technical Courier, 61(1), pp.21-45.

Tam, W.M., Lau, F.C.M., \& Tse, C.K. 2004. A Multiple Access Scheme for ChaosBased Digital Communication Systems Utilizing Transmitted Reference. IEEE Transactions on Circuits and Systems I: Regular Papers, 51(9), pp.1868-1878. doi:10.1109/TCSI.2004.834497.

Torrieri, D., Mukherjee, A., \& Kwo, H.M. 2010. Coded DS-CDMA Systems with Iterative Channel Estimation and no Pilot Symbols. IEEE Trans. on Wireless Comm., 9(6), pp.2012-2021.

Vali, R., Berber, S., \& Nguang, S.K. 2010. Analysis of a Chaos-based Non-coherent Delay Lock Tracking Loop. . In: International Conference on Communications, Cape Town, pp.1-5.

Vali, R., Berber, S., \& Nguang, S.K. 2010. Effect of Rayleigh fading on noncoherent sequence synchronization for multi-user chaos based DS-CDMA. Signal Processing, 90(6), pp.1924-1939.

Verdú, S. 1998. Multiuser Detection.Cambridge, MA: Cambridge University Press.

Vukadinovic, S., \& Berber, S. 2006. Theory, Design and Implementation of Chaotic Sequence Generators in CB-CDMA Systems, No 642.Auckland: Auckland University. School Report, p.30.

Wang, L. 2005. Support Vector Machines: Theory and Applications.Berlin: Springer.

W.M.Tam, , F.C.M.Lau, , C.K.Tse, , \& Lawrance, A.J. 2004. Exact Analytical Bit Error Rates for Multiple Access Chaos-Based Communication Systems. IEEE Transactions on Circuits and Systems II: Express Briefs, 51(9), pp.473-481. doi:10.1109/TCSII.2004.832773.

Xiao, P., \& Strom, E. 2010. Soft Demodulation for Orthogonal Modulated and Convolutionally Coded DS-CDMA Systems.IEEE Trans.on Comm., 58(3), pp.742-747.

Yang, T., \& Hu, B. 2005. Study of Multiuser Detection: The Support Vector Machine Approach. pp.442-451.

Yang, T., \& Hu, B. 2006. Blind multiuser detection based on kernel approximation. Heidelberg, Germany: Springer., vol. 3973, pp.94-101. 
Yue, L., Weerasinghe, N.S., Han, C., \& Hashimoto, T. 2010. Partial Multiuser Detection for CS-CDMA/CP over Multipathh Channels. IEEE Trans.on Comm, 58(8), pp.2305-2313.

Zhao, X., \& Kuh, A. 2002. Adaptive kernel least square support vector machines applied to recover DS-CDMA signals. .In: Proc. 36th Asilomar Conf. Signals Syst. Comput, pp.943-947.

\title{
ПРОТОТИП МНОГОПОЛЬЗОВАТЕЛЬСКОЙ СИСТЕМЫ, ОСНОВАННОЙ НА КОРЕЛЛЯЦИОННЫХ ПРИЕМНИКАХ ИЛИ ОПОРНЫХ ВЕКТОРАХ
}

\author{
Стеван М. Бербер \\ The University of Auckland, ECE Department, Новая Зеландия
}

ОБЛАСТЬ: телекоммуникации, беспроводная система коммуникации ВИД СТАТЬИ: оригинальная научная статья

ЯЗЫК СТАТЬИ: английский

Резюме:

Технология многопользовательской системы коммуникации с кодовым распределением каналов (CDMA) используется в современных беспроводных сетях, таких как сотовые, радиотелефонные сети и беспроводные сенсорные сети.

Развитие передачи сигнала на фризическом уровне в сети, основано на применении двоичных последовательностей в расширении зоны сигнала и применении корреляционных приемников.

В данной работе описана разработка приемопередатчика CDMA сигналов, при применении новых коммуникационных методов, основанных на хаотической последовательности в расширении зоны сигналов, обеспечивая тем самым защиту передачи сообщений в системе, применяя методы новых технологиях обнаружения сигналов при использовании машины опорных векторов в приемнике (SVM - приемник) и традиционного применения корреляционных приемников.

Проведен теоретический анализ обеих моделей приемников, включая вывод вычисления вероятности битовых ошибок в каналах с замираниями (федингом) сигналов, затем произведено внедрение в цифрровые технологии (DSP) на 32-битовую процессорную платформу TigerSHARC.

Сопоставление этих систем показало, что решение применения машины опорных векторов (SVM - приемник) улучшает робастность системы за счет снижения скорости потока.

В то время как осуществленный поток битов корреляционного приемника в два раза превышает поток битов приемника машины опорных векторов.

Ключевые слова: прямохаотические системы связи; SVM корреляционный приемник; CDMA системы; DSP развитие CDMA систем. 
PROTOTIP VIŠEUČESNIČKOG SISTEMA BAZIRANOG NA PRIJEMNICIMA SA KORELATORIMA ILI MAŠINOM PODRŽAVAJUĆIH VEKTORA

Stevan M. Berber

The University of Auckland, ECE Department, Novi Zeland

OBLAST: telekomunikacije, bežični komunikacioni sistemi

VRSTA ČLANKA: originalni naučni članak

JEZIK ČLANKA: engleski

Sažetak:

Tehnike višeučesničkih komunikacija sa kodnom raspodelom kanala (CDMA) koriste se u modernim bežičnim mrežama kao što su mobilne radio-telefonske mreže i bežične senzorske mreže.

Razvoj prenosa signala na fizičkom nivou u ovim mrežama zasnovan je na primeni binarnih sekvenci za proširenje signala i primeni korelatorskih prijemnika. U ovom radu prikazan je razvoj primopredajnika za prenos CDMA signala korišćenjem nove komunikacione metode zasnovane na primeni haotičnih sekvenci za proširenje signala, čime se može povećati zaštita u prenosu poruka u sistemu, i razvojem nove tehnike detekcije signala korišćenjem mašina sa podržavajućim vektorima u prijemniku (SVM prijemnik) i tradicinalno korišćenog korelatorskog prijemnika. Oba razvijena prijemnika su teorijski analizirana, uključujući izvode izraza za verovatnoću greške bita u zatvorenom obliku u slučaju kanala sa fedingom, a zatim je izvršena njihova implementacija u digitalnoj tehnologiji (DSP) na 32-bitnoj procesorskoj platformi TigerSHARC. Poređenje ova dva sistema pokazalo je da rešenje sa mašinom sa podržavajućim vektorima (SVM prijemnik) poboljšava robustnost sistema po cenu smanjenja brzine procesiranja. Međutim, ostvarljivi protok bita kod prijemnika sa korelatorom bio je dva puta veći nego kod prijemnika koji koristi mašinu sa podržavajućim vektorima.

Uvod

Ovih godina porastao je interes da se optimizuju prijemnici u bežičnim komunikacijama radi potrebe za prenosom velike količine podataka $i$ ostvarenja energetske efikasnosti, posebno u području mobilnih komunikacionih sistema i bežičnih senzorskih mreža. Radi ovih zahteva očekuje se novi razvoj u oblasti dizajna prijemnika kako bi se smanjila njihova složenost i povećala energetska efikasnost.

Da bi se ostvario prenos vešeučesničkih signala može da se koristi tehnika prenosa sa kodnom raspodelom kanala (CDMA), koja omogućava istovremenu komunikaciju više učesnika u istom komunikacionom sistemu tako da se svakom učesniku dodeli jedinstvena kodna sekvenca kojom se proširuje signal poruke u predajniku i koja se koristi u prijemniku kako bi se otkrio sadržaj poslate poruke. Razvoj prijemnika ovih sistema tradicionalno se zasnivao na primeni usklađenih filtera i korelatora. 
U poslednje vreme došlo je do preliminarnih istraživanja o mogućoj primeni mašina sa podržavajućim vektorima (SVM), kao jednoj od alternativa za dizajn prijemnika za CDMA sisteme, zbog njihove sposobnosti da prevladaju među-učesničku interferenciju i da se prilagode na dinamične komunikacione zahteve u odnosu na broj učesnika i karakteristike sekvenci za proširenja signala. Međutim, do sada nema radova koji govore o hardverskoj implemantaciji ili praktičnoj primeni ovakvih prijemnika, što je bila dodatna motivacija autoru da objavi rezultate istraživanja o dizajnu prototipa ovog sistema.

Kommunikacioni sistemi koji koriste haotične sekvence bili su predmet značajnih istraživanja, a posebno CDMA sistemi koji koriste klasične $i$ haotične sekvence za proširenje signala, pri čemu je problem robustne sinhronizacije naširoko ispitivan. Većina radova analiziralo je ove sisteme za slučaj prisutnosti ravnog fedinga u kanalu prenosa. Detaljna analiza CDMA sistema sa širokopojasnim, frekvencijski selektivnim kanalima urađena je tek u poslednje vreme. Zbog ograničene ortogonalnosti sekvenci za proširenje signala dolazi do povećanja interučesničke interferencije sa povećanjem broja učesnika u CDMA sistemu. Da bi se prevladao ovaj problem razvijeni su multiučesnički detektori, a posebno detektori koji su zasnovani na primeni mašina sa podržavajućim vektorima (SVM).

Uprkos tome što su SVM tehnike primenjene za detekciju signala, nije bilo objavljenih radova koje prikazuju razvoj ovih uređaja u digitalnoj (DSP) tehnologiji. Ova činjenica motivisala je autora da prikaže svoje rezultate u vezi s dizajnom i testiranjem prototipa CDMA sistema uporedo sa rezultatima analize sistema koji koristi korelatorski prijemnik radi upoređenja ovih sistema. Karakteristike oba prototipa sa aspekta stepena greške bita (eng. $B E R$ ) upoređene su i prikazane odnosne karakteristike teorijskog i simulacionog modela. Provedena teorijska i simulaciona analiza pokazale su prednosti tehnike SVM-a i dobro slaganje teorijskih i praktičnih rezultata.

Pošto izraz za verovatnoću greške bita nije još bio izveden u zatvorenom obliku za SVM CDMA sistem, autor je izveo ovaj izraz i prezentirao grafove za stepen greške bita (BER). Pokazano je da se ovako dobijeni grafovi za BER slažu sa odgovarajućim grafovima koji su dobijeni numeričkom integracijom, što dokazuje validnost izvedene teorijske formule.

U radu su upoređena dva sistema - sistem sa SVM prijemnikom i sistem sa korelatorskim prijemnikom, i pokazano je da korelatorski prijemnik ostvaruje veći digitalni protok. Što se tiče kompleksnosti dizajna, dokazano je da SVM prijemnik zahteva duže vreme za procesiranje signala. Prikazana procedura poređenja i dobijeni grafovi su rezultati vredni pažnje.

Višeučesnički sistem zasnovan na korišćenju haotičnih sekvenci i SVM prijemnika

U ovom odeljku prikazana je blok-šema SVM prijemnika i objašnjen princip rada svih blokova. Objašnjen je princip generisanja haotičnih sekvenci i prikazana funkcija korelacije i unakrsne korelacije u grafičkoj formi. Posebno je objašnjen princip rada SVM detektora. Izvedeni su izrazi za verovatnoću greške bita u zatvorenom obliku za SVM prijemnik u slučaju kada je u kanalu prisutan šum i ravni feding. 
Razvoj i implementacija sistema sa SVM i korelatorskim prijemnikom

Definisan je uskopojasni kanal sa ravnim fedingom. Takođe, izvršena je matematička analiza sistema, tako što su prikazani signali na ključnim tačkama prijemnika i predajnika. Prikazan je izraz za signal na izlazu korelatora sekvenci, a zatim izveden izraz za verovatnoću greške bita u zatvorenom obliku i analiziran sa aspekta uticaja broja učesnika u sistemu i sa aspekta vrednosti faktora proširenja signala.

Prikazane su karakteristike DSP platforme na kojoj je urađen prototip sistema, tako što su objašnjene osnovne karakteristike DSP ploče proizvođača Analog Devices. Prikazana je blok-šema razvijenog sistema i objašnjen princip njenog rada. Naglašeno je da struktura prototipa veoma dobro prati strukturu teorijskog i simulacionog modela o kojima je bilo reči na početku rada. Objašnjena je procedura generisanja haotičnih sekvenci sa posebnim osvrtom na problem generisanja aperiodičnih sekvenci. Pri razvoju sistema korišćena je Boks-Milerova metoda za generisanje Gausovog šuma, koja se zasniva na generisanju dva niza nezavisnih slučajnih uzoraka koji imaju uniformnu funkciju distribucije verovatnoća. Poslednja sekcija posvećena je problemu tačne estimacije vrednosti BER -a za definisanu vrednost odnosa signal-šum.

Razvoj SVM detektora i sklopa odluke

U ovom delu objašnjeno je kako se generišu vektori podrške i podaci treninga za definisani broj učesnika i određeni faktor proširenja signala. Podaci treninga prikazani su u formi izvesnog broja uzoraka kao rezultat obrade u korelatoru. Broj uzoraka zavisi od vrednosti odnosa signal-šum. Da bi se generisali vektori podrške na osnovu ovih podataka, koji su memorisani u posebnom fajlu, nastavljen je trening uz korišćenje iterativnog algoritma. Rezultat ovog treninga je fajl podataka koji sadrži parametre kao što je težinski faktor, centralna vrednost i pristranost vektora podrške.

Rezultati ispitivanja i upoređenja prototipa sa teorijskim i simulacionim modelom

$U$ ovom odeljku prikazani su procedura i rezultati testiranja prototipa, uključujući: analizu verovatnoće greške bita u kanalu sa šumom sa odnosnim grafovima za slučajeve kada su jedan ili četiri učesnika prisutani u sistemu, zatim verovatnoću greške bita kada je ravni feding prisutan u kanalu sa odnosnim grafovima za 10 i 30 učesnika, i na kraju, kratku analizu stepena greške bita koji se može ostvariti korišćenjem korelatorskog prijemnika u odnosu na SVM prijemnik, čime je pokazano da SVM prijemnik ostvaruje manji bitski protok nego korelatorski prijemnik.

\section{Zaključak}

Urađen je razvoj prototipa CDMA sistema, koji koristi haotične sekvence i SVM prijemnik, pri čemu je korišćena razvojna platforma 32-bitnog ADSP-TS201S TigerSHARC procesora. Ovaj prototip razvijen je tako što su funkcije sistema implementirane u C jeziku na procesoru koji je smešten na TS201S EZ-KIT Lite razvojnoj platformi. Potvrđeno je da se na ovoj platformi može implementirati prototip koji sledi simulacioni i teorijski model. 
Korićena je faza treninga da bi se generisali podržavajući vektori koristeći Matlab program. Izveden je izraz za verovatnoću greške bita u zatvorenom obliku za slučaj kada je ravni feding prisutan u kanalu prenosa signala. Merenjem na prototipu sistema pokazano je da je stepen greške bita bolji kod prijemnika sa SVM nego kod korelatorskog prijemnika. Vrednosti stepena greške bita prototipa, za različite faktore proširenja i promenljivi broj učesnika, slažu se sa odgovarajućim vrednostima dobijenim na simulacionom i teorijskom modelu.

Očekivani problem periodičnosti haotičnih sekvenci proširenja signala zbog konačne rezolucije u DSP dizajnu rešen je tako što se vršila ponovljena inicijalizacija generatora sekvenci. Pošto su se teorijski i eksperimentalni rezultati dobro poklopili očigledno je da DSP rezolucija nema uticaja na performanse sistema.

Rezultati ocene brzine obrade signala pokazali su da CDMA sistem sa korelatorskim prijemnikom ima veći bitski protok nego SVM prijemnik, što je rezultat dužeg procesiranja signala pri računanju podržavajućih vektora. Ova brzina procesiranja ostvarena na prototipu ne može da zadovolji povećane potrebe za bitskim protokom u realnim sistemima. Međutim, veoma korisna iskustva stečena su prilikom razvoja ovog pototipa i sagledane mogućnosti kako da se procesiranje ubrza kroz optimizaciju algoritama i primenu novih digitalnih tehnologija. Mogući pravac budućih istraživanja mogao bi da bude usmeren ka izradi prototipa sistema koji koristi metode eliminacije fedinga, kao što je metoda učešljavanja čipova.

Ključne reči: haotični komunikacioni sistemi, SVM i korelatorski prijemnik, CDMA sistemi, DSR razvoj CDMA sistema.

Datum prijema članka / Дата получения работы / Paper received on: 26. 08. 2015.

Datum dostavljanja ispravki rukopisa / Дата получения исправленной версии работы / Manuscript corrections submitted on: 24. 10. 2015.

Datum konačnog prihvatanja članka za objavljivanje / Дата окончательного согласования работы / Paper accepted for publishing on: 26. 10. 2015.

(c) 2016 Autor. Objavio Vojnotehnički glasnik / Military Technical Courier (www.vtg.mod.gov.rs, втг.мо.упр.срб). Ovo je članak otvorenog pristupa i distribuira se u skladu sa Creative Commons licencom (http://creativecommons.org/licenses/by/3.0/rs/).

( 2016 Автор. Опубликовано в "Военно-технический вестник / Vojnotehnički glasnik / Military Technical Courier" (www.vtg.mod.gov.rs, втг.мо.упр.срб). Данная статья в открытом доступе и распространяется в соответствии с лицензией "Creative Commons" (http://creativecommons.org/licenses/by/3.0/rs/).

(C) 2016 The Author. Published by Vojnotehnički glasnik / Military Technical Courier (www.vtg.mod.gov.rs, втг.мо.упр.срб). This article is an open access article distributed under the terms and conditions of the Creative Commons Attribution license (http://creativecommons.org/licenses/by/3.0/rs/). 